\title{
Dimethoate inhibits steroidogenesis by disrupting transcription of the steroidogenic acute regulatory (StAR) gene
}

\author{
L P Walsh, D R Webster and D M Stocco
}

Department of Cell Biology and Biochemistry, Texas Tech University Health Sciences Center, Lubbock, Texas 79430, USA

(Requests for offprints should be addressed to D M Stocco; Email: Doug.Stocco@ttmc.ttuhsc.edu)

\begin{abstract}
Dimethoate is a widely used organophosphate insecticide that has been shown to disrupt reproductive function in animals. Although the pathogenesis of Dimethoateinduced reproductive toxicity remains to be determined, a reduction in serum testosterone levels is thought to play an important role in the development of Dimethoate-induced infertility. Since Leydig cells play a crucial role in male reproductive function by producing testosterone, the mouse MA-10 Leydig tumor cell line was used to determine if Dimethoate can directly block steroid hormone biosynthesis and to identify the site of steroidogenic inhibition. Dimethoate inhibited steroidogenesis in both a dose- and time-dependent manner without affecting total protein synthesis or protein kinase A activity. While it
\end{abstract}

decreased the activity of the P450 side chain cleavage (P450 scc) enzyme, a reduction in the activity of this enzyme alone could not account for the level of $\mathrm{Bu}_{2} \mathrm{CAMP}-$ inhibited progesterone production. Instead, our results suggest that Dimethoate inhibited steroidogenesis primarily by blocking transcription of the steroidogenic acute regulatory (StAR) gene. This finding is significant since StAR protein mediates the rate-limiting and acutely-regulated step in steroidogenesis, the transfer of cholesterol from the outer to the inner mitochondrial membrane. This study indicates that StAR may be an important target for environmental pollutants which disrupt steroidogenesis and impair reproductive function.

Journal of Endocrinology (2000) 167, 253-263

\section{Introduction}

The recent increase in the agricultural use of organophosphorus pesticides may threaten the reproductive health of humans and wildlife. Since organophosphorus pesticides are rapidly degraded in the environment, they have largely replaced organochlorine insecticides, which can bioaccumulate and biomagnify. Unfortunately, studies have shown that organophosphate compounds have a much greater acute toxicity than organochlorine compounds and can cause male reproductive failure following repeated exposure (Pope 1999). Indeed, interest in the potential adverse reproductive effects of these compounds has heightened in recent years as a result of studies which show that several organophosphorus compounds including Dimethoate, methyl parathion, malathion, dichlorvos, chlorpyrifos and dimethyl-methylphosphate impair fertility, suppress libido, deteriorate semen quality and cause testicular degeneration in rodents following repeated exposure (Krause \& Homola 1974, Krause 1977, Haas et al. 1983, Dunnick et al. 1984).

Not only is Dimethoate a commonly used agricultural insecticide and acaricide, but it is also listed (Comprehensive Environmental Response, Compensation and Liability Act (CERCLA) priority list of hazardous substances) as one of the contaminants at hazardous waste sites that pose the most significant potential threat to human health (United States Department of Health and Human Services 1997). In fact, investigators have shown that repeated exposure to Dimethoate decreases serum testosterone levels, testicular weight, and sperm motility and increases the percentage of dead and abnormal sperm in rats and rabbits (Salem et al. 1988, Afifi et al. 1991). Moreover, it accumulates in the testes where it persists for weeks even after its oral administration is stopped (Afifi et al. 1991). Since spermatogenesis and fertility are critically dependent upon the maintenance of adequate levels of testosterone, the ability of Dimethoate to reduce serum testosterone levels might contribute to the reduction in spermatogenesis and fertility observed in animals exposed to this pesticide.

Although organophosphates may reduce serum steroid hormone levels by increasing steroid catabolism and elimination, several studies have demonstrated that these compounds can directly inhibit steroid hormone production. Dichlorvos, dursban, diazinon, chlorpyrifos, furadan, and isopropyl bicyclic phosphate have all been shown to inhibit steroidogenesis in adrenal cells (Civen \& Brown 1974, Civen et al. 1977). Importantly, these compounds block both adrenocorticotropin- and cAMP-stimulated 
steroidogenesis but not pregnenolone-driven steroid production, indicating that they target the steroidogenic pathway between the formation of cAMP and the production of pregnenolone (Civen \& Brown 1974, Civen et al. 1977). This finding is significant since this part of the pathway includes the true rate-limiting step in steroidogenesis, the transfer of cholesterol to the P450 side chain cleavage (P450 scc) enzyme, as well as the rate-limiting enzymatic step in steroidogenesis, the P450 scc enzyme itself.

The rate-limiting and acutely regulated step in hormone-stimulated steroidogenesis is the delivery of cholesterol from the outer to the inner mitochondrial membrane where the P450 scc enzyme initiates the synthesis of all steroid hormones (Stocco \& Clark 1996). Numerous reports indicate that the steroidogenic acute regulatory (StAR) protein mediates this rate-limiting step in steroidogenesis. StAR protein is rapidly synthesized in response to cAMP, its active form has a very short half-life, and it rapidly increases the movement of cholesterol from the outer to the inner mitochondrial membrane (for review see Stocco \& Clark 1996). Transfection of steroidogenic cells with StAR expression vectors or nonsteroidogenic cells with StAR and the cholesterol side chain cleavage enzyme system increases steroidogenesis at least sixfold (Clark et al. 1994). Furthermore, mutations in the human StAR gene cause the disease lipoid congenital adrenal hyperplasia, a potentially lethal condition in which adrenal and gonadal steroidogenesis is greatly reduced (Lin et al. 1995).

As StAR protein mediates the transfer of cholesterol to the P450 scc complex, and the P450 scc enzyme catalyzes the conversion of cholesterol to pregnenolone, Dimethoate may block steroidogenesis by targeting these components of the steroidogenic pathway. Therefore, the present studies were undertaken to determine if Dimethoate could directly inhibit steroidogenesis in the mouse MA-10 Leydig tumor cell line and, if so, to determine the site of steroidogenic inhibition by measuring its effects on the activities and expression of the steroidogenic enzymes and StAR protein.

\section{Materials and Methods}

\section{Chemicals}

Waymouth's MB 752/1 medium, horse serum, gentamicin sulfate, lyophilized trypsin-EDTA, phosphatebuffered saline with $\mathrm{Ca}^{2+}$ and $\mathrm{Mg}^{2+}\left(\mathrm{PBS}^{+}\right)$, and phosphate-buffered saline without $\mathrm{Ca}^{2+}$ and $\mathrm{Mg}^{2+}\left(\mathrm{PBS}^{-}\right)$ were purchased from Gibco Life Technologies (Gaithersburg, MD, USA). [1,2,6,7-N- $\left.{ }^{3} \mathrm{H}(\mathrm{N})\right]$-progesterone (specific activity (SA), $97 \mathrm{Ci} / \mathrm{mmol}$ ) and $\left[7-{ }^{3} \mathrm{H}(\mathrm{N})\right]-$ pregnenolone $(\mathrm{SA}, 21 \mathrm{Ci} / \mathrm{mmol})$ were obtained from New England Nuclear (Boston, MA, USA). Antibodies to progesterone were obtained from Holly Hills Biological (Hillsboro, OR, USA). SU 10603, cyanoketone, and antibodies to pregnenolone were generously provided by
Dr Focko Rommerts (Erasmus University, Rotterdam, The Netherlands). Percoll and dextran T70 were obtained from Pharmacia Fine Chemicals (Uppsala, Sweden). Nunc cell culture dishes, charcoal (Norit), trichloroacetic acid (TCA), scintiverse $\mathrm{BD}$ and sodium bicarbonate were obtained from Fisher Scientific (Houston, TX, USA). Acrylamide, bis acrylamide, and SDS were purchased from Bio-Rad (Hercules, CA, USA). Bovine serum albumin (BSA), $\mathrm{Bu}_{2} \mathrm{cAMP}, 22(\mathrm{R})$-hydroxycholesterol (22R$\mathrm{HC})$, pregnenolone, and progesterone were purchased from Sigma (St Louis, MO, USA). Dimethoate $(480 \mathrm{~g} / 1$ dimethoate) O,O-dimethyl S-methylcarbamoylmethyl phosphorodithioate was obtained from the BASF Corporation, Agricultural Products Group (Research Triangle Park, NC, USA). Rabbit antisera to amino acids 88-98 of mouse StAR protein was generated by Research Genetics (Huntsville, AL, USA). Rabbit antisera to amino acids 421-441 of rat P450 scc enzyme was purchased from Chemicon (Temecula, CA, USA). Antisera to purified

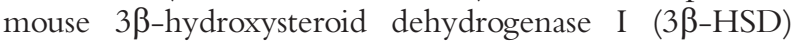
was a gift from Dr Allesandro Capponi, University of Geneva (Geneva, Switzerland). Horseradish peroxidaseconjugated donkey anti-rabbit IgG was purchased from Amersham (Arlington Heights, IL, USA). StAR cDNA was previously cloned in our laboratory (Clark et al. 1994). Bovine P450 scc cDNA was obtained from Dr Michael Waterman, Vanderbilt University (Nashville, TN, USA); mouse $3 \beta-H S D$ I cDNA was provided by Dr Anita Payne, Stanford University (Stanford, CA, USA); mouse L-19 and $18 \mathrm{~S}$ rRNA cDNAs were obtained from from Dr Gail Cornwall, Texas Tech University Health Sciences Center (Lubbock, TX, USA).

\section{MA-10 cell culture}

The mouse MA-10 Leydig tumor cell line was a gift from Dr Mario Ascoli, University of Iowa College of Medicine (Iowa City, IA, USA). Cells were maintained in Waymouth's MB 752/1 medium $+15 \%$ horse serum at $37^{\circ} \mathrm{C}$ and $5 \% \mathrm{CO}_{2}$ as described previously (Ascoli 1981). For dose-response, time-course, steroidogenic enzyme activity and reversibility studies, 75000 cells were seeded into each well of a 96-well plate and grown overnight. For nuclear run-on analysis, $50 \times 10^{6}$ cells were seeded onto $25 \times 25 \mathrm{~cm}$ tissue culture dishes and grown overnight. For the remaining studies, $1.5 \times 10^{6}$ cells were plated into $100 \mathrm{~mm}$ culture dishes and grown until $80 \%$ confluent. For all experiments, medium was removed, cells were washed twice with $\mathrm{PBS}^{+}$and serum-free Waymouth's medium containing the appropriate treatment was placed on the cells.

\section{Treatment of cells}

MA-10 cells were stimulated using maximal doses of $\mathrm{Bu}_{2} \mathrm{CAMP}(1 \mathrm{mM})$. In some studies, optimal concentrations of $22 \mathrm{R}-\mathrm{HC}(25 \mu \mathrm{M})$ or pregnenolone $(10 \mu \mathrm{M})$ 
were provided as steroidogenic substrate. All treatments were performed in serum-free media. Final concentrations of DMSO and ethanol used as chemical solvents were less than $0 \cdot 4 \%$ and were included in controls.

\section{Dose-response and time-course studies}

In dose-response and time-course studies, the effects of Dimethoate on steroidogenesis and total cellular protein synthesis were determined. In dose-response studies, MA-10 cells grown in 96-well plates were stimulated with $\mathrm{Bu}_{2} \mathrm{cAMP}$ for $2 \mathrm{~h}$ in the presence and absence of various concentrations of Dimethoate. The concentration of Dimethoate required to reduce progesterone production by $50 \%\left(\mathrm{IC}_{50}\right)$ was calculated using linear regression analysis. Eadie/Hofstee plots ([progesterone] vs [progesterone]/ [Dimethoate]) of the dose-response data were made (Nagy \& Freeman 1990). The slope of the line equals the $\mathrm{IC}_{50}$ value. In time-course studies, MA-10 cells grown in 96-well plates were stimulated with $\mathrm{Bu}_{2} \mathrm{cAMP}$ in the presence or absence of various concentrations of Dimethoate for 2 or $4 \mathrm{~h}$.

\section{RIA}

Quantitation of progesterone in the medium was performed by RIA as previously described (Resko et al. 1974). Quantitation of pregnenolone in the medium was performed essentially as described for progesterone except that pregnenolone-specific reagents were used. Analysis of RIA data was performed using a software program which was written by Mr Bennie Shaw (Texas Tech University Health Sciences Center). Data are expressed as ng/ml media. For progesterone, the intra-assay and interassay variations were $3 \%$ and $11 \%$ respectively. For pregnenolone, the intra-assay and interassay variations were $11 \%$ and $20 \%$ respectively. The progesterone antibody has $35 \%$ cross-reactivity with 5 $\alpha$-androstane-3-17-dione. The pregnenolone antibody has $29 \%, 21 \%$ and $12 \%$ cross-reactivity with cortisol, 17 $\beta$-estradiol, and progesterone respectively.

\section{Determination of total cellular protein synthesis}

To determine the effects of compounds on total protein synthesis, cells grown in 96-well plates were treated as described above with the inclusion of $5 \mu \mathrm{Ci} / \mathrm{ml}$ Expre ${ }^{35} \mathrm{~S}^{35} \mathrm{~S}$ Protein Labeling Mix (SA, $1000 \mathrm{Ci} / \mathrm{mmol}$; New England Nuclear). Determination of total protein by a modification of the Bradford method (Bradford 1976) was performed on identically plated cells that were not treated with Expre ${ }^{35} \mathrm{~S}^{35} \mathrm{~S}$. Following treatment, media were removed and cells were solubilized for $2 \mathrm{~h}$ in $0.25 \mathrm{M}$ $\mathrm{NaOH}$ at $37^{\circ} \mathrm{C}$. Next, an equal volume of cold $20 \%$ TCA was added and protein was precipitated overnight at $4{ }^{\circ} \mathrm{C}$. TCA-precipitable material was transferred onto glass fiber filters using a 1225 Sampling Manifold (Millipore,
Bedford, MA, USA) and rinsed with 5\% TCA, dried and counted in a liquid scintillation counter. Results were expressed as counts per minute per sample, 2 or $4 \mathrm{~h}$.

\section{Protein kinase $A$ activity determination}

Protein kinase A (PKA) activity was measured with the SignaTECT cAMP-dependent protein kinase assay system (Promega, Madison, WI, USA) as described in the manufacturer's protocol. This assay measures the transfer of ${ }^{32} \mathrm{P}$ to the biotinylated PKA peptide substrate, Kemptide (LRRASLG). Cells grown in $100 \mathrm{~mm}$ plates were treated as described for $4 \mathrm{~h}$. Following treatment, cells were collected in extraction buffer $(25 \mathrm{mM}$ Tris- $\mathrm{HCl}$, pH $7 \cdot 4, \quad 0.5 \mathrm{mM}$ EDTA, $0.5 \mathrm{mM}$ EGTA, $10 \mathrm{mM}$ $\beta$-mercaptoethanol, $1 \mu \mathrm{g} / \mathrm{ml}$ leupeptin, and $1 \mu \mathrm{g} / \mathrm{ml}$ aprotinin), homogenized at 1000 r.p.m. with 25 passes using a Potter Elvehjem homogenizer fitted with a Teflon pestle and centrifuged at $13000 \times \mathbf{g}$ for $10 \mathrm{~min}$. The supernatant was used directly for both the kinase assay and protein measurement by the Bradford method. Approximately $3 \mu \mathrm{g}$ protein were incubated for $10 \mathrm{~min}$ at $30^{\circ} \mathrm{C}$ in $40 \mathrm{mM}$ Tris- $\mathrm{HCl}, \mathrm{pH} 7 \cdot 4,20 \mathrm{mM} \mathrm{MgCl}, 0 \cdot 1 \mathrm{mg} / \mathrm{ml}$ BSA, $0 \cdot 1 \mathrm{mM}$ biotinylated Kemptide, $0 \cdot 1 \mathrm{mM}$ ATP, and $0.02 \mu \mathrm{Ci} / \mu \mathrm{l} \quad\left[\gamma_{-}{ }^{32} \mathrm{P}\right] \mathrm{dATP}$ (SA, $3000 \mathrm{Ci} / \mathrm{mmol}$; New England Nuclear). In some cases, to ensure specificity for PKA activity, the PKA inhibitor PKI (Promega) was added. Reactions were stopped by the addition of $7 \cdot 5 \mathrm{M}$ guanidine-HCl. Ten microliters of the reaction mix were spotted onto a streptavidin-coated membrane that specifically binds biotinylated Kemptide. Unincorporated $\left[\gamma-{ }^{32} \mathrm{P}\right] \mathrm{dATP}$ and non-biotinylated protein were then removed by extensive washing. The incorporation of ${ }^{32} \mathrm{P}$ into biotinylated Kemptide bound to the membrane was determined by liquid scintillation counting. PKA activity was expressed as picomoles ${ }^{32} \mathrm{P}$ incorporated per minute per milligram protein.

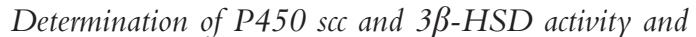 reversibility}

The effects of xenobiotics on the combined activities of the P450 scc and $3 \beta-H S D$ enzymes were determined by adding $22 \mathrm{R}-\mathrm{HC}$ to MA-10 cells in the presence or absence of the xenobiotic for $2 \mathrm{~h}$ and measuring progesterone production. To determine reversibility, in some experiments cells were then rinsed with $\mathrm{PBS}^{+}$, allowed to recover for $24 \mathrm{~h}$ in serum-containing medium, and incubated again for $2 \mathrm{~h}$ with $\mathrm{Bu}_{2} \mathrm{cAMP}$ and/or 22R-HC. Then, progesterone in the media was measured. To evaluate $\mathrm{P} 450 \mathrm{scc}$ enzyme activity, 22R-HC was provided as substrate to MA-10 cells in the presence and absence of appropriate xenobiotic as well as cyanoketone and SU 10603 , inhibitors of $3 \beta$-HSD and $17 \alpha$-hydroxylase/ $17,20-$ lyase (P450c17) respectively, for $2 \mathrm{~h}$, and pregnenolone in the medium was measured. To evaluate $3 \beta-$ HSD enzyme activity, pregnenolone was provided as 
substrate and MA-10 cells were treated in the presence and absence of the xenobiotic for $2 \mathrm{~h}$, and progesterone in the media was measured.

\section{Isolation of mitochondria and Western blot analysis}

Cells were treated as described above for determination of PKA activity. Mitochondria were isolated by homogenization and differential centrifugation (Clark et al. 1994). Then, Western blot analysis of mitochondrial protein was performed as previously described (Wang et al. 1998). Following detection of StAR, the membrane was stripped in $62.5 \mathrm{mM}$ Tris- $\mathrm{HCl}(\mathrm{pH} 6.8), 2 \%$ SDS, and $100 \mathrm{mM}$ $\beta$-mercaptoethanol at $70{ }^{\circ} \mathrm{C}$ for $30 \mathrm{~min}$, washed in $10 \mathrm{mM}$ Tris- $\mathrm{HCl}(\mathrm{pH} 7 \cdot 4)$ and $150 \mathrm{mM} \mathrm{NaCl}$ twice for $10 \mathrm{~min}$, and then successively probed with P450 scc or 3 $3-\mathrm{HSD}$ antisera. The bands of interest were quantitated using a BioImage Visage 2000 (BioImage Corp., Ann Arbor, MI, USA) imaging system. Values obtained were expressed as integrated optical density units (IOD), as previously described (Stocco \& Kilgore 1988).

\section{Isolation of RNA and Northern blot analysis}

Cells were treated as described above for determination of PKA activity. Then, total RNA was isolated using Trizol reagent (Gibco BRL, Grand Island, NY, USA), according to the manufacturer's protocol. RNA was quantitated and resuspended in RNA sample buffer $(0.1 \times$ borate buffer, $48 \%$ formamide, $6 \cdot 4 \%$ formaldehye, $5 \cdot 3 \%$ glycerol and $0 \cdot 27 \%$ Bromophenol Blue). Northern blot analysis was performed as previously described (Sutton et al. 1999). Twenty micrograms total RNA were loaded into each well. Labeling of cDNA probes for mouse StAR, P450 scc, $3 \beta-H S D$, and $18 S$ rRNA was achieved by random priming (Prime-It II; Stratagene, La Jolla, CA, USA) using $\left[\alpha-{ }^{32} \mathrm{P}\right] \mathrm{dCTP}$ (SA, $3000 \mathrm{Ci} / \mathrm{mmol}$; New England Nuclear), according to the manufacturer's protocol. After hybridization, the blots were washed twice in $2 \times$ SSC, $1 \%$ SDS at room temperature for $30 \mathrm{~min}$, and once in $0.1 \times \mathrm{SSC}$, $0 \cdot 1 \%$ SDS at $65^{\circ} \mathrm{C}$ for $30 \mathrm{~min}$. Following Northern blot analysis with StAR cDNA, blots were stripped by washing twice in $0 \cdot 1 \times \mathrm{SSC}, 1 \% \mathrm{SDS}$ at $65^{\circ} \mathrm{C}$ for $30 \mathrm{~min}$, and then successively probed with $\mathrm{P} 450 \mathrm{scc}, 3 \beta-\mathrm{HSD}$, and $18 \mathrm{~S}$ rRNA cDNA. The bands of interest were quantitated and the values obtained were expressed as described above.

\section{Isolation of nuclei and nuclear run-on analysis}

MA-10 cells grown in $25 \times 25 \mathrm{~cm}$ tissue culture dishes were stimulated with $\mathrm{Bu}_{2} \mathrm{cAMP}$ in the presence and absence of the appropriate xenobiotic for $4 \mathrm{~h}$. Isolation of nuclei and nuclear run-on analysis were performed as described in Greenburg and Bender (1998). For isolation of nuclei following treatment, cells were harvested with a rubber policeman and centrifuged for $5 \mathrm{~min}$ at $500 \times \mathbf{g}$,
$4{ }^{\circ} \mathrm{C}$. The cell pellet was resuspended in ice-cold Sucrose I buffer $(0.32 \mathrm{M}$ sucrose, $3 \mathrm{mM} \mathrm{CaCl}, 2 \mathrm{mM}$ magnesium acetate, $0.1 \mathrm{mM}$ EDTA, $1 \mathrm{mM}$ dithiothreitol (DTT), 0.5\% (v/v) Nonidet P-40 (NP-40), 10 mM Tris-HCl, $\mathrm{pH}$ $8 \cdot 0$ ), and homogenized with 5 strokes of a Dounce homogenizer. To verify that nuclei were free of cytoplasmic tags, nuclei were inspected with an Olympus IMT-2 inverted microscope (Dexter Instrument Co., San Antonio, TX, USA). Then, the homogenate was layered onto a sucrose cushion consisting of Sucrose II buffer (2 M sucrose, $5 \mathrm{mM}$ magnesium acetate, $0.1 \mathrm{mM}$ EDTA, $1 \mathrm{mM}$ DTT, $10 \mathrm{mM}$ Tris-HCl, $\mathrm{pH} \mathrm{8.0)}$, and centrifuged for $45 \mathrm{~min}$ at $30000 \times \mathbf{g}, 4{ }^{\circ} \mathrm{C}$. The supernatant was discarded and the pellet containing nuclei was resuspended in ice-cold Glycerol Storage buffer (40\% (v/v) glycerol, $5 \mathrm{mM} \mathrm{MgCl} 2,0 \cdot 1 \mathrm{mM}$ EDTA, $50 \mathrm{mM}$ Tris- $\mathrm{HCl}, \mathrm{pH}$ $8 \cdot 3)$, frozen on dry ice and stored in liquid nitrogen.

Equal numbers of nuclei were used in the in vitro transcription assay, and equal counts of RNA were hybridized to target StAR, L-19 and 18S cDNA inserts as well as linearized, empty pCMV-5 vector previously immobilized to nylon membranes (Hybond $\mathrm{N}+$ ) using a Bio-Dot SF microfiltration apparatus (Bio-Rad) according to the manufacturer's protocol. Prehybridization and hybridization were performed under the same conditions described for Northern blots. Radioactivity was detected using a Phosphorimager 445 SI (Molecular Dynamics, Sunnyvale, CA, USA). Signals were quantitated using ImageQuant v4.1 software (Molecular Dynamics). Values were obtained from the phosphorimager as arbitrary units.

\section{Statistical analysis}

Statistically significant differences between treatments and controls were determined by one-way ANOVA and Fisher-protected least significant difference multiple comparison. Statistical analysis was performed using the software program Statview SE+Graphics (Abacus Concepts, Inc., Berkeley, CA, USA).

\section{Results}

Effects of Dimethoate on progesterone production, total cellular protein synthesis and protein kinase $A$ activity

For dose-response and time-course studies, MA-10 cells were stimulated with $\mathrm{Bu}_{2} \mathrm{cAMP}$ in the presence or absence of Dimethoate (Fig. 1). This pesticide decreased progesterone production in a dose-dependent manner $\left(\mathrm{IC}_{50}=21 \pm 3.09 \mu \mathrm{g} / \mathrm{ml}\right)$ without producing a concomitant decrease in total protein synthesis, thus excluding acute toxicity and a general disruption in translation as mechanisms of steroidogenic inhibition. Since Dimethoate $(50 \mu \mathrm{g} / \mathrm{ml})$ significantly $(P<0 \cdot 05)$ reduced steroidogenesis by $65 \%$ without affecting total protein synthesis, we chose 


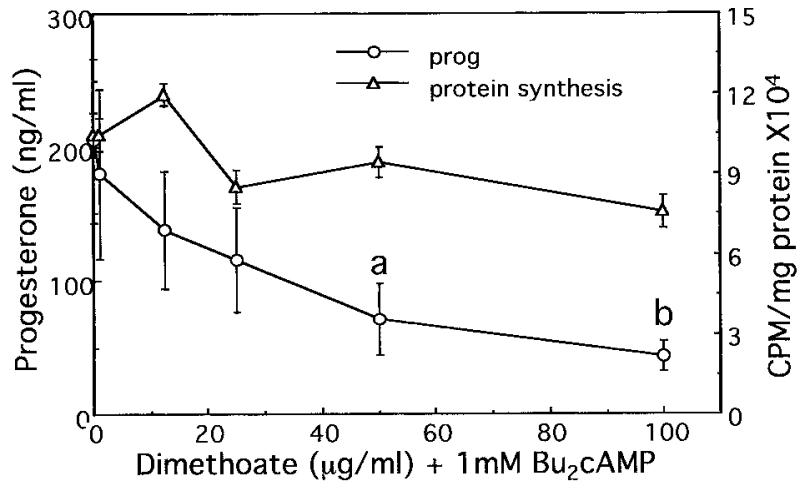

Figure 1 Effects of Dimethoate on progesterone production and total cellular protein synthesis in MA-10 cells. Cells were stimulated with $\mathrm{Bu}_{2} \mathrm{CAMP}$ in the presence or absence of various concentrations of Dimethoate for $2 \mathrm{~h}$ and the medium was assayed for progesterone. In some cases, $5 \mu \mathrm{Ci} / \mathrm{ml}$ Expre ${ }^{35} \mathrm{~S}^{35} \mathrm{~S}$ Protein Labeling Mix was added to the cells. In these cases, following treatment, the medium was removed, cells were rinsed, and total cellular protein synthesis was assayed as described in Materials and Methods. For progesterone production, each data point is the average \pm S.E.M. from at least three separate experiments in which treatments were performed in quadruplicate. For protein synthesis, each data point is the mean \pm S.E.M. of four replicates in a single experiment which was performed three times. Statistically significant differences are designated with an (a) $P<0 \cdot 05$ or (b) $P<0 \cdot 001$.

to use this dose for the remaining studies. This pesticide also significantly $(P<0 \cdot 001)$ disrupted steroidogenesis over time without inducing a parallel decrease in total protein synthesis (Table 1).

A reduction in PKA activity might provide a simple explanation for the reduction in steroidogenesis. However, Dimethoate did not affect the ability of PKA in cell lysates to phosphorylate the PKA-specific substrate, Kemptide (LRRASLG) (data not shown).

Effects of Dimethoate on P450 scc and 3 $\beta$-HSD enzyme activity and expression, and steroidogenesis following a 24- $h$ recovery

To determine if the inhibitory effect of Dimethoate on $\mathrm{Bu}_{2} \mathrm{CAMP}-$ stimulated progesterone production might be due to an inhibition of the activities of the steroidogenic enzymes, P450 scc and/or 3 $\beta-\mathrm{HSD}, 22 \mathrm{R}-\mathrm{HC}$ was provided as a substrate and cells were treated for $2 \mathrm{~h}$ with Dimethoate (50 $\mu \mathrm{g} / \mathrm{ml}$; Fig. 2A). The water soluble cholesterol analog $22 \mathrm{R}-\mathrm{HC}$ was used since it can readily diffuse to the P450 scc enzyme located on the inner mitochondrial membrane, bypassing the need for StAR-mediated cholesterol transfer.

Although Dimethoate significantly $(P<0 \cdot 01)$ reduced $\mathrm{Bu}_{2} \mathrm{cAMP}-$ stimulated steroidogenesis by $76 \%, \mathrm{Bu}_{2} \mathrm{CAMP}-$ stimulated progesterone production in these cells returned to control levels following a 24-h recovery, indicating that its effects on steroidogenesis were completely reversible (Fig. 2B). Dimethoate also significantly $(P<0 \cdot 05)$ reduced 22R-HC-driven steroidogenesis by $63 \%$, indicating that it inhibited P450 scc and/or 3 $\beta-\mathrm{HSD}$ enzyme activity. However, as $\mathrm{Bu}_{2} \mathrm{cAMP}+22 \mathrm{R}-\mathrm{HC}$-stimulated steroid production was only reduced by $43 \%$ after $2-\mathrm{h}$ treatment, this shows that $22 \mathrm{R}-\mathrm{HC}$ could partially reverse the inhibition of $\mathrm{Bu}_{2} \mathrm{cAMP}-$ stimulated steroidogenesis.

To determine if Dimethoate specifically disrupted $3 \beta-$ HSD, P450 scc or both steroidogenic enzyme activities, both pregnenolone-driven progesterone production (a measure of $3 \beta-\mathrm{HSD}$ activity) and 22R-HC-driven pregnenolone production (a measure of $\mathrm{P} 450 \mathrm{scc}$ activity) were measured following herbicide treatment for $2 \mathrm{~h}$ (Fig. 3).

Table 1 Time-course study of the effects of Dimethoate on progesterone production and total cellular protein synthesis in MA-10 cells. MA-10 cells grown in 96-well plates were stimulated with $\mathrm{Bu}_{2} \mathrm{CAMP}$ in the presence and absence of $50 \mu \mathrm{g} / \mathrm{ml}$ Dimethoate for 2 or $4 \mathrm{~h}$. Then, the medium was removed and assayed for progesterone, and total protein synthesis was also measured. For progesterone production, each data point is the average \pm S.E.M. of the means from at least three separate experiments in which treatments were performed in quadruplicate. For protein synthesis, each data point is the mean \pm S.E.M. of four replicates in a single experiment which was performed three times

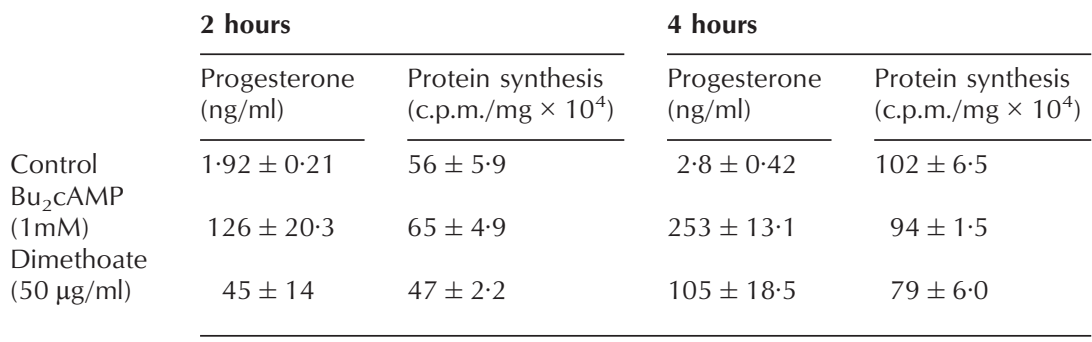

For progesterone production at 2 and $4 \mathrm{~h}$, the difference between $\mathrm{Bu}_{2} \mathrm{CAMP}$ and Dimethoate+ $\mathrm{Bu}_{2} \mathrm{CAMP}$ was statistically significant $(P<0 \cdot 001)$. 

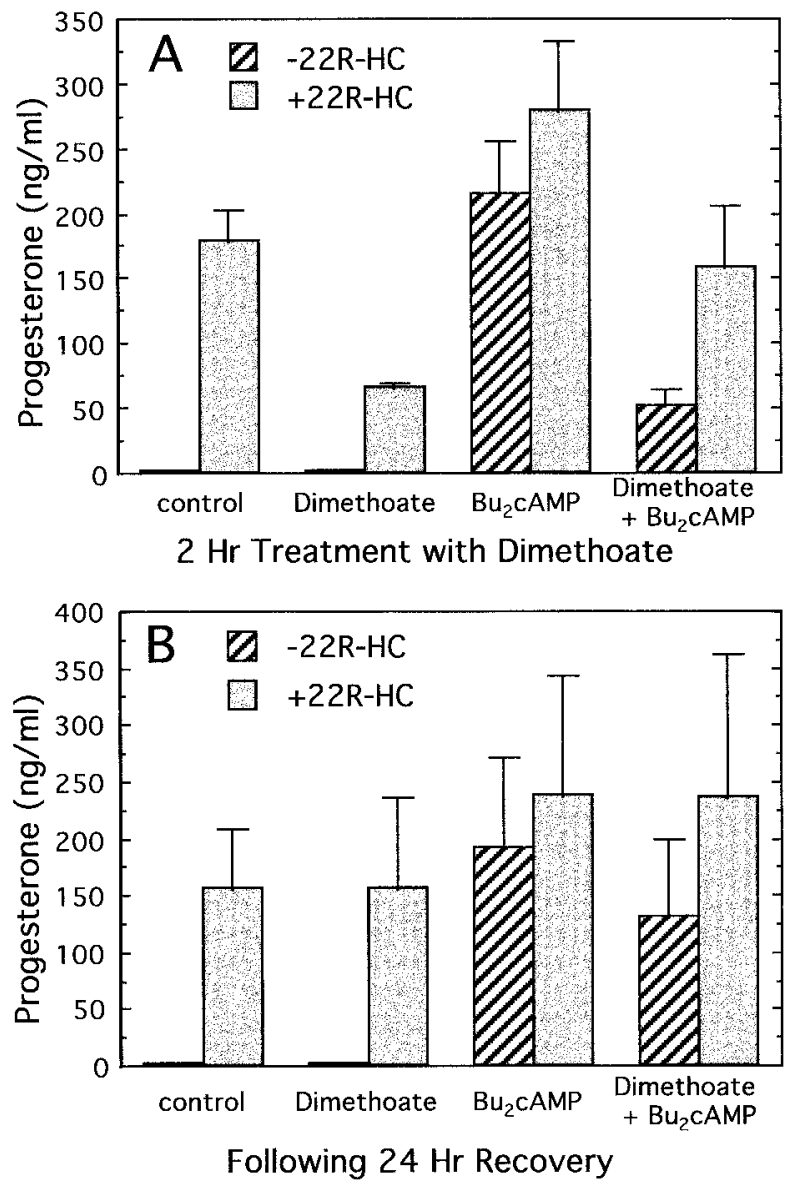

Figure 2 Effects of Dimethoate on P450 scc and 3 $\beta$-HSD enzyme activity and steroidogenesis following a 24-h recovery in MA-10 cells. 22R-HC-stimulated cells grown in 96-well plates were treated for $2 \mathrm{~h}$ with Dimethoate $(50 \mu \mathrm{g} / \mathrm{ml})$, and medium was assayed for progesterone. To determine reversibility, cells were rinsed with $\mathrm{PBS}^{+}$, incubated in serum-containing medium for $24 \mathrm{~h}$, and stimulated again for $2 \mathrm{~h}$ with $22 \mathrm{R}-\mathrm{HC}$ and/or $\mathrm{Bu}_{2} \mathrm{CAMP}$, and medium was assayed for progesterone. (A) Effects of 2-h treatment with Dimethoate on progesterone production. The difference between $\mathrm{Bu}_{2} \mathrm{CAMP}$ and Dimethoate was statistically significant $(P<0 \cdot 01)$. (B) Effects of 2 -h treament with Dimethoate on progesterone production following a 24-h recovery. Each data point represents the average \pm S.E.M. from at least three separate experiments in which treatments were performed in quadruplicate.

Although Dimethoate did not alter $3 \beta-H S D$ enzyme activity, indicating that the herbicide was not acutely toxic to cells or mitochondria, it significantly $(P<0 \cdot 01)$ reduced P450 scc activity by $49 \%$.

To determine if the decrease in P450 scc enzyme activity might be due to a reduction in the levels of this enzyme, and to confirm that $3 \beta-H S D$ enzyme levels were not affected, the effects of Dimethoate on the expression of these enzymes were determined. As Fig. 4 shows, Dimethoate significantly blocked steroidogenesis by $81 \%$. However, Western blot analysis of mitochondrial protein
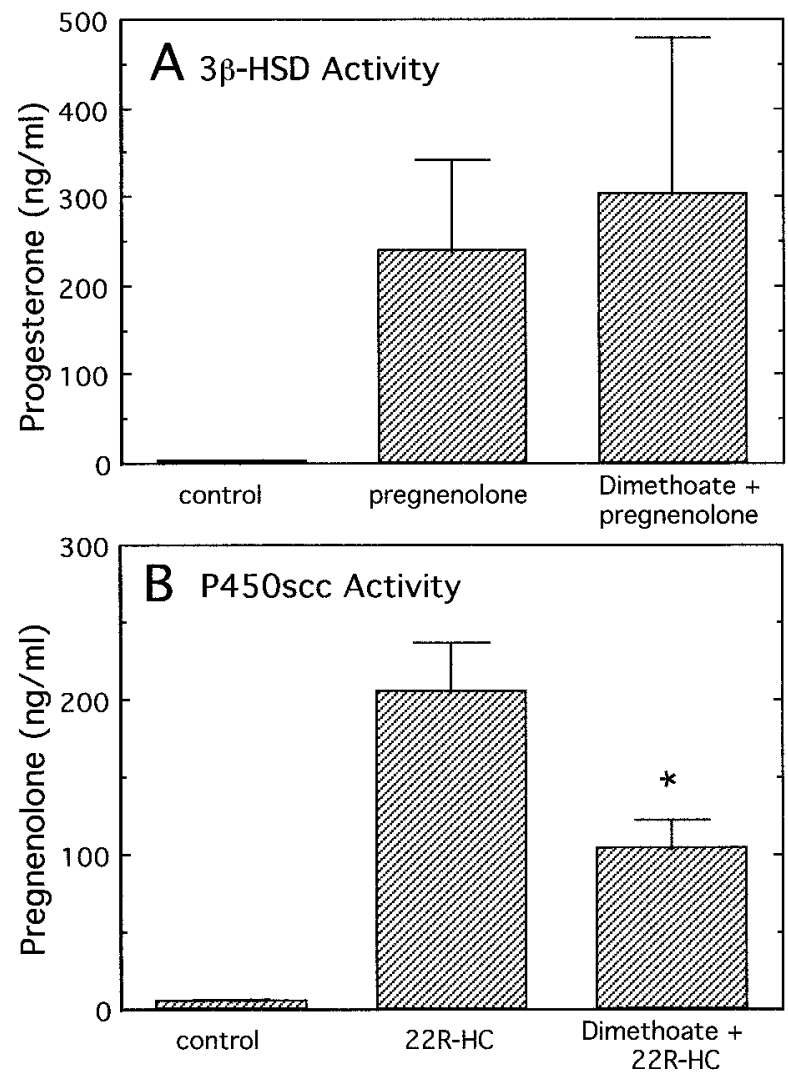

Figure 3 Effects of Dimethoate on $3 \beta-H S D$ and P450 scc enzyme activity. To evaluate $3 \beta$-HSD enzyme activity, cells grown in 96-well plates were treated with $50 \mu \mathrm{g} / \mathrm{ml}$ Dimethoate in the presence of the substrate, pregnenolone $(10 \mu \mathrm{M})$, for $2 \mathrm{~h}$. Then, medium was assayed for progesterone. To evaluate P450 scc enzyme activity, 22R-HC-stimulated cells were treated with $50 \mu \mathrm{g} / \mathrm{ml}$ Dimethoate as well as with $5 \mu \mathrm{M}$ cyanoketone and $19 \mu \mathrm{M}$ SU 10603, inhibitors of 3 $\beta$-HSD and P450c17 respectively, for $2 \mathrm{~h}$. The medium was assayed for pregnenolone. (A) Effects of Dimethoate on $3 \beta$-HSD enzyme activity. (B) Effects of Dimethoate on P450 scc enzyme activity. Each data point represents the average \pm S.E.M. from at least six separate experiments in which treatments were performed in quadruplicate. Statistically significant differences $(P<0.01)$ are designated with an asterisk.

revealed that it did not alter $\mathrm{P} 450 \mathrm{scc}$ or $3 \beta-\mathrm{HSD}$ enzyme levels (Figs 5 and 6, upper panels). Moreover, Northern blot analysis revealed that Dimethoate did not affect P450 scc mRNA levels (Fig. 5, lower panel). Surprisingly, Dimethoate significantly $(P<0 \cdot 01)$ reduced $3 \beta-\mathrm{HSD}$ mRNA levels by 33\% (Fig. 6, lower panel).

\section{Effects of Dimethoate on StAR expression}

Since StAR protein mediates the transfer of cholesterol to the inner mitochondrial membrane, an action which constitutes the rate-limiting step in steroidogenesis, the effects of Dimethoate on the levels of this protein were also 


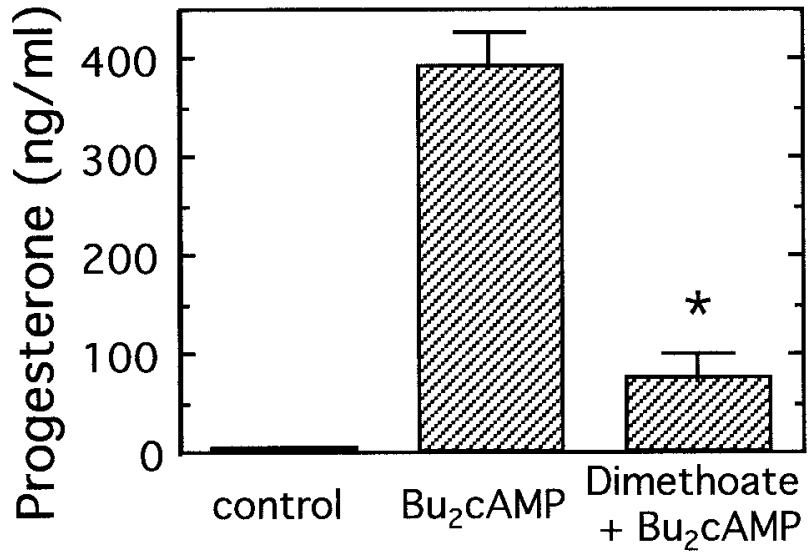

Figure 4 Effects of Dimethoate on progesterone production in MA-10 cells. Cells grown in 100-mm plates were treated with Dimethoate $(50 \mu \mathrm{g} / \mathrm{ml})$ for $4 \mathrm{~h}$. Then, medium was assayed for progesterone. Each data point represents the average \pm S.E.M. from six separate experiments in which treatments were performed in triplicate. Statistically significant differences $(P<0 \cdot 001)$ are designated with an asterisk.

determined. Western blot analysis revealed that this pesticide dramatically reduced StAR protein levels by $83 \%$ (Fig. 7A).

To determine the effects of Dimethoate on StAR mRNA levels, Northern blot analysis was performed. StAR mRNA consists of the $1 \cdot 6,2 \cdot 7$, and $3 \cdot 4 \mathrm{~kb}$ transcripts which comprise $18 \%, 10 \%$, and $72 \%$ respectively of total StAR mRNA (Fig. 7B). Northern blot analysis revealed that Dimethoate reduced total StAR mRNA levels by $81 \%$. Moreover, this pesticide significantly $(P<0 \cdot 01)$ decreased levels of the most abundant $3.4 \mathrm{~kb}$ StAR transcript by $86 \%$ (Fig. $7 \mathrm{~B}$ ).

To determine if Dimethoate reduced StAR protein levels by blocking StAR transcription, nuclear run-on analysis was performed. As Fig. 8 shows, $\mathrm{Bu}_{2} \mathrm{cAMP}$ increased the rate of StAR gene transcription fivefold. However, Dimethoate decreased StAR transcription by $55 \%$, indicating that it primarily reduced StAR protein expression and steroidogenesis at the level of transcription.

\section{Discussion}

The present study showed that Dimethoate directly blocked $\mathrm{Bu}_{2} \mathrm{CAMP}-$ stimulated steroid hormone production in MA-10 cells, an effect which most likely can be attributed to a reduction in StAR transcription. This observation is consistent with earlier reports which have shown that other organophosphate compounds can directly block the steroidogenic pathway between the formation of cAMP and the production of pregnenolone in rat adrenal cell primary cultures (Civen \& Brown 1974, Civen et al. 1977). Since we have previously

\section{A Western Analysis}

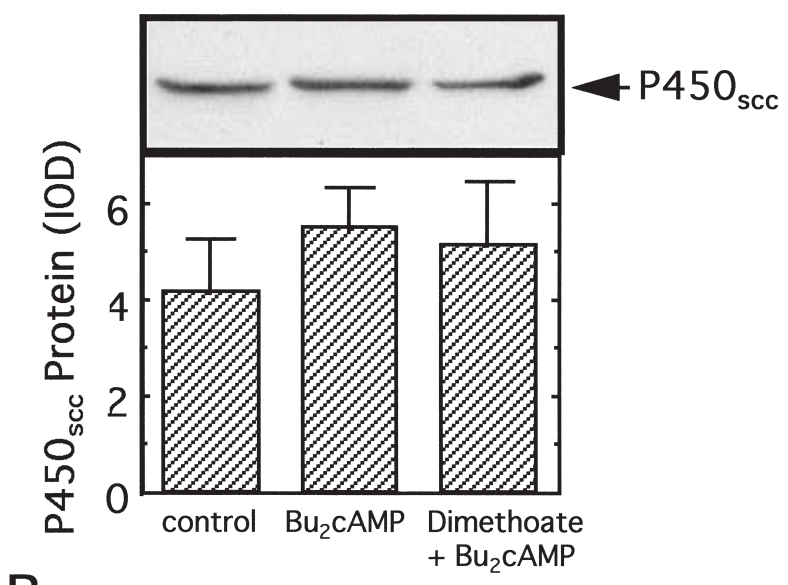

B Northern Analysis

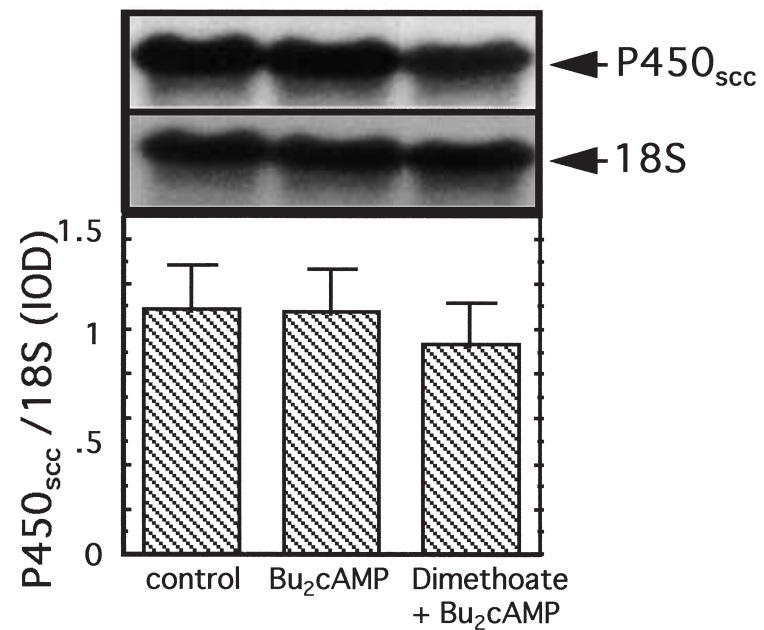

Figure 5 Effects of Dimethoate on P450 scc enzyme and mRNA levels. Cells were treated as described in Fig. 4. (A) Western blot analysis of mitochondrial protein was performed as described in Materials and Methods. In the upper panel, a representative Western blot is shown. (Lower panel) Immunospecific bands for the P450 scc enzyme were quantitated by computer assisted image analysis. (B) Northern blot analysis of total cellular RNA was performed as described in Materials and Methods. In the upper panel, representative Northern blots for P450 scc mRNA and 18S rRNA are shown. (Lower panel) Bands for P450 scc mRNA and $18 \mathrm{~S}$ rRNA were quantitated and data expressed as P450 scC mRNA/18S rRNA. Each data point represents the average \pm S.E.M. from three separate experiments in which treatments were performed in triplicate.

demonstrated with another organophosphorus compound, diethylumbelliferyl phosphate, that steroidogenesis in MA-10 cells can be inhibited by blocking StAR protein expression (Choi et al. 1995), these findings indicate the possibility that organophosphorus compounds as a class 


\section{A Western Analysis}

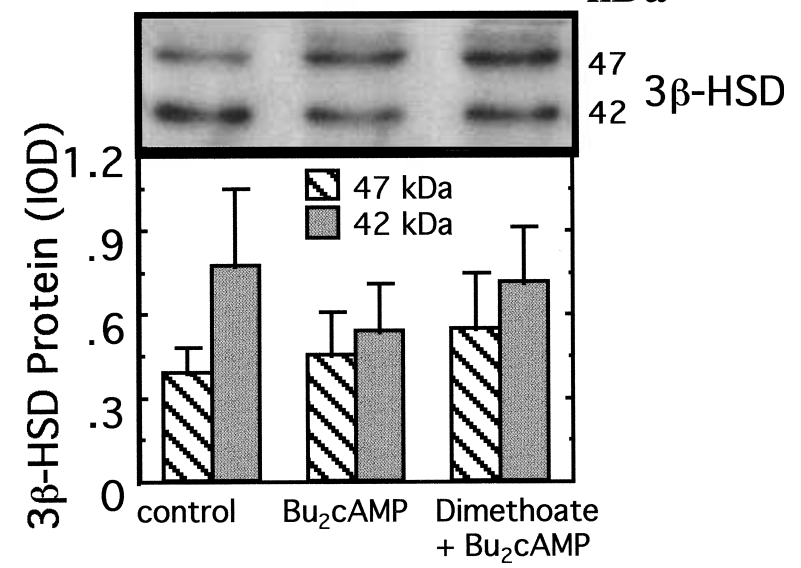

\section{B Northern Analysis}

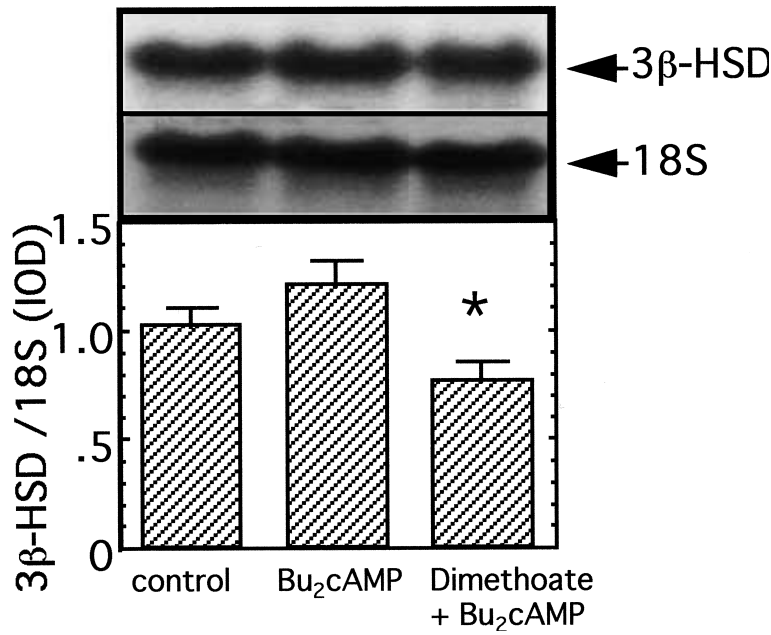

Figure 6 Effects of Dimethoate on 3 $\beta$-HSD enzyme and mRNA levels. Cells were treated as described in Fig. 4. (A) Western blot analysis of mitochondrial protein was performed as described in Materials and Methods. In the upper panel, a representative Western blot is shown. In the lower panel, immunospecific bands for the 3 $\beta$-HSD enzyme were quantitated by computer assisted image analysis. (B) Northern blot analysis of total cellular RNA was performed as described in the Materials and Methods. In the upper panel, representative Northern blots for 3 $\beta$-HSD mRNA and $18 \mathrm{~S}$ rRNA are shown. In the lower panel, bands for $3 \beta-\mathrm{HSD}$ mRNA and 18S rRNA were quantitated and data expressed as $3 \beta$-HSD mRNA/18S rRNA. Each data point represents the average \pm S.E.M. from three separate experiments in which treatments were performed in triplicate. Statistically significant differences $(P<0 \cdot 01)$ are designated with an asterisk.

may block steroidogenesis through a common mechanism of action.

Previous studies concerning StAR gene expression in MA-10 cells have shown that cAMP increases StAR steady-state mRNA levels in parallel with StAR protein
A Western Analysis

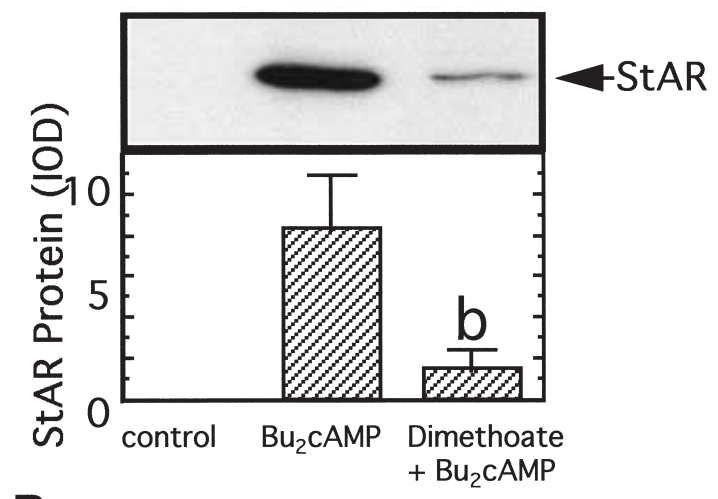

\section{B Northern Analysis}

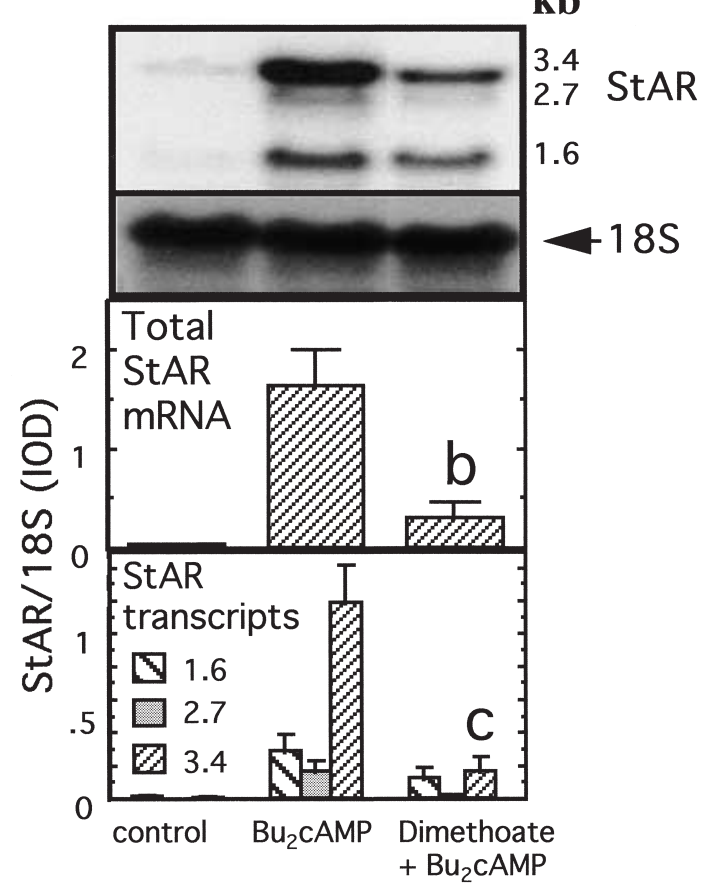

Figure 7 Effects of Dimethoate on StAR protein and mRNA levels. Cells were treated as described in Fig. 4. (A) Western blot analysis of mitochondrial protein was performed as described in Materials and Methods. In the upper panel, a representative Western blot is shown. In the lower panel, immunospecific bands for the StAR protein were quantitated by computer assisted image analysis. (B) Northern blot analysis of total cellular RNA was performed as described in Materials and Methods. In the upper panel, representative Northern blots for StAR mRNA and 18S rRNA are shown. (Middle and lower panels) Bands corresponding to the $3 \cdot 4,2 \cdot 7$, and $1 \cdot 6 \mathrm{~kb}$ transcripts of StAR mRNA and $18 \mathrm{~S}$ rRNA were quantitated and data expressed as (middle panel) the sum of StAR transcripts' IOD/18S rRNA IOD or (lower panel) individual StAR transcript IOD/18S rRNA IOD. Each data point represents the average \pm S.E.M. from three separate experiments in which treatments were performed in triplicate. Statistically significant differences are designated with (b) $P<0.01$ or (c) $P<0 \cdot 001$. 


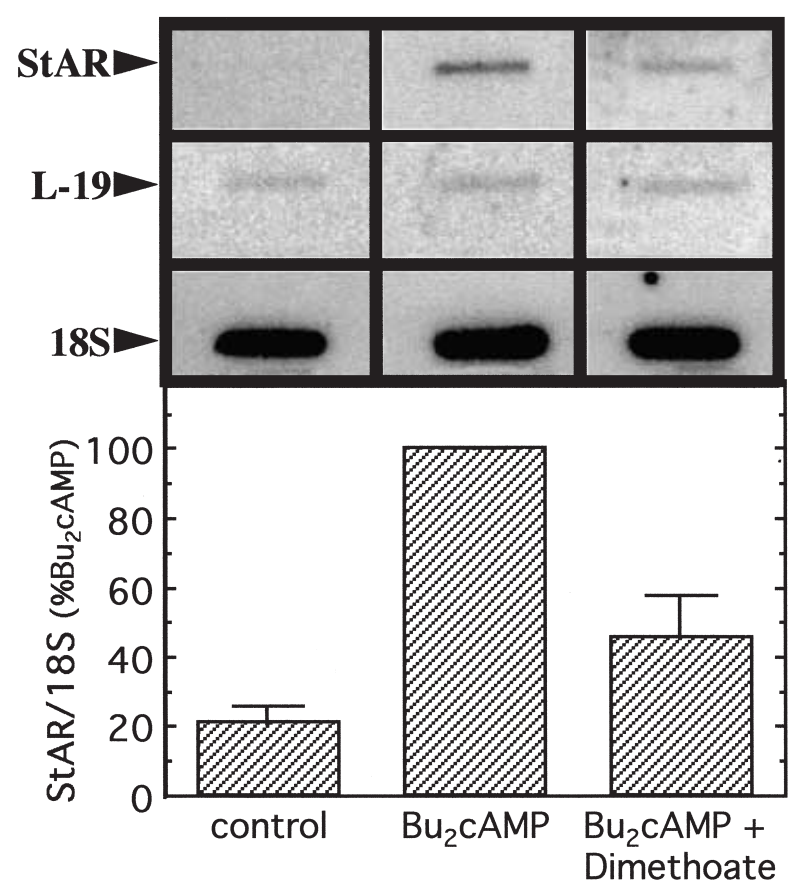

Figure 8 Effects of Dimethoate on StAR gene transcription. Nuclear run-on analysis was performed on MA-10 cells grown in $25 \times 25 \mathrm{~cm}$ tissue culture plates stimulated with $\mathrm{Bu}_{2}$ CAMP in the presence or absence of $50 \mu \mathrm{g} / \mathrm{ml}$ Dimethoate for $4 \mathrm{~h}$. In the upper panel, a representative experiment is shown. (Lower panel) Bands for StAR, L-19 mRNA and 18S rRNA were quantitated by computer assisted image analysis. StAR was normalized to $18 \mathrm{~S}$ for each treatment, and data are expressed as a percentage of StAR/18S of $\mathrm{Bu}_{2} \mathrm{CAMP}$-treated cells. Each data point represents the average \pm S.E.M. of five separate experiments.

levels and steroid production (Clark et al. 1995), and that these events require new transcription (Clark et al. 1997). Therefore, a reduction in the rate of StAR gene transcription can account for the reduction in steroidogenesis. Although previous reports indicate that cAMP responsiveness is conveyed within the first $254 \mathrm{bp}$ of the StAR promoter and that a number of transcription factors including steroidogenic factor-1 (SF-1) and CCAAT/enhancer binding protein- $\beta$ are required for basal StAR transcription, the proteins involved in hormone-stimulated StAR protein expression are poorly defined (Reinhart et al. 1999). Therefore, further studies are needed to determine the mechanism by which Dimethoate reduces StAR transcription.

Tropic hormone-regulated steroidogenesis has an absolute requirement for the synthesis of new proteins. In fact, as StAR is a cycloheximide-sensitive protein, a general reduction in protein synthesis could have explained the decrease in StAR protein levels and thus steroid production (Garren et al. 1965). However, Dimethoate at concentrations as high as $100 \mu \mathrm{g} / \mathrm{ml}$ failed to affect total protein synthesis in MA-10 cells (this study) or in the human leukemia cell line, HL-60 (Marinovich et al. 1994), indicating that it did not inhibit steroidogenesis by causing acute cellular toxicity or by inducing a general disruption in translation. These studies indicate that Dimethoate may have disrupted steroidogenesis by targeting specific sites within the cell.

In Leydig cells, tropic hormone regulates steroid hormone production primarily through the cAMP second messenger pathway. Once synthesized, cAMP activates cAMP-dependent PKA which, in turn, phosphorylates several proteins involved in the regulation of steroidogenesis, including StAR protein, cholesterol ester hydrolase, and perhaps other as yet unidentified proteins that must be phosphorylated for steroidogenesis to occur (Stocco \& Clark 1993). While a reduction in PKA activity could have explained the inhibition of steroid production and reduction in StAR protein levels, the present results indicate that Dimethoate did not alter PKA activity. However, as the phosphorylation of StAR and other proteins were not directly measured and alternative mechanisms such as an increase in protein phosphatase activity might be involved, changes in protein phosphorylation status cannot be ruled out at this time.

Although the present study shows that Dimethoate reduced P450 scc activity following acute exposure, a reduction in StAR protein expression alone could account for Dimethoate's effects on steroidogenesis, suggesting that the inhibition of P450 scc activity has little physiological significance, its activity being distal to StAR function. The P450 scc enzyme is part of the cholesterol side chain cleavage enzyme system (CSCC) which also includes adrenodoxin reductase and adrenodoxin. The electrons required for the conversion of cholesterol to pregnenolone are transfered from NADPH to adrenodoxin reductase to adrenodoxin and finally to the P450 scc enzyme (Simpson 1979). Thus, Dimethoate could have directly targeted the enzyme's active site or affected the availability and/or activity of cofactors and reducing equivalents. However, further studies are necessary to determine how Dimethoate affects P450 scc enzyme activity.

Although Dimethoate slightly reduced $3 \beta-H S D$ mRNA levels, it failed to alter $3 \beta$-HSD activity following acute exposure. Like Dimethoate, a reduction in $3 \beta-\mathrm{HSD}$ mRNA levels has been observed following treatment with tumor necrosis factor-alpha and interleukin-1 beta (Xiong \& Hales 1997) although, again, the mechanism remains unclear. As the $3 \beta-\mathrm{HSD}$ enzyme is chronically regulated and has a long half-life, a more protracted exposure to Dimethoate may reduce the levels of this enzyme and may ultimately contribute to the decline in the cell's steroidogenic capacity.

Three important differences in the regulation of StAR expression may render it susceptible to chemical modulation compared with the steroidogenic enzymes. First, in 
Leydig cells StAR protein expression is mainly dependent upon luteinizing hormone (LH) stimulation, making its expression more vulnerable to chemicals which inhibit the LH signaling pathway. It has very low expression in the absence of LH and is rapidly synthesized to high levels following tropic hormone stimulation. In contrast, with the exception of $\mathrm{P} 450 \mathrm{c} 17$, the steroidogenic enzymes are constitutively expressed at high levels, retain near normal steroidogenic capacity in the absence of LH for extended periods of time, and are only increased several-fold by $\mathrm{LH}$ after a lag of several hours (for review see Payne \& O'Shaughnessy 1996). Secondly, as StAR protein mediates the rate-limiting step in steroidogenesis, steroid production is very sensitive to alterations in its expression. In contrast, with the exception of the P450 scc enzyme which can limit the cell's steroidogenic capacity (Nolan \& Payne 1990), a reduction in steroidogenic enzyme levels does not cause a concomitant reduction in steroid production. In fact, inhibitors can reduce P450c17 levels by as much as $90 \%$ without decreasing the cell's steroidogenic capacity (Anakwe \& Payne 1987). Finally, unlike the steroidogenic enzymes which have long half-lives and are chronically regulated, the active form of the StAR protein is highly labile and must be continuously synthesized for steroidogenesis to occur. Providing evidence that StAR protein may indeed be a target for endocrine disrupting chemicals, recent studies have shown that the herbicide Roundup, the pesticide lindane, and the antifungal drugs econazole and miconazole inhibit steroidogenesis by reducing StAR protein expression (Walsh \& Stocco 1999, 2000a,b, Walsh et al. 2000).

In conclusion, Dimethoate inhibits steroid hormone production in MA-10 cells by reducing StAR transcription. As other compounds have been shown to reduce steroidogenesis by disrupting StAR protein expression, this may represent a common mechanism by which some endocrine disruptors inhibit steroidogenesis. Although Dimethoate has been shown to disrupt testicular function in laboratory animals, further studies are required to determine if Dimethoate and other contemporary use pesticides pose a real threat to humans and wildlife.

\section{Acknowledgements}

The authors would like to acknowledge the technical assistance of Ms Deborah Alberts. This work was supported by NIH Grant HD17481 (D M S). L P W was supported by NIH Grant T32-HD07271 and a scholarship from the Lubbock Achievement Rewards for College Scientists (ARCS) Chapter.

\section{References}

Afifi NA, Ramadan A, el-Aziz MI \& Saki EE 1991 Influence of dimethoate on testicular and epididymal organs, testosterone plasma level and their tissue residues in rats. DTW Deutsch Tierarztliche Wochenschrift 98 419-423.

Anakwe OO \& Payne AH 1987 Noncoordinate regulation of de novo synthesis of cytochrome P-450 cholesterol side chain cleavage and cytochrome P-450 17 alpha- hydroxylase/C17-20 lyase in mouse Leydig cell cultures: relation to steroid production. Molecular Endocrinology 1 595-603.

Ascoli M 1981 Characterization of several clonal lines of cultured Leydig tumor cells: gonadotropin receptors and steroidogenic responses. Endocrinology 108 88-95.

Bradford MM 1976 A rapid and sensitive method for the quantitation of microgram quantities of protein utilizing the principle of protein-dye binding. Analytical Biochemistry 72 248-254.

Choi YS, Stocco DM \& Freeman DA 1995 Diethylumbelliferyl phosphate inhibits steroidogenesis by interfering with a long-lived factor acting between protein kinase A activation and induction of the steroidogenic acute regulatory protein (StAR). European Journal of Biochemistry 234 680-685.

Civen M \& Brown CB 1974 The effect of organophosphate insecticides on adrenal corticosterone formation. Pesticide Biochemistry and Physiology 4 254-259.

Civen M, Lifrak E \& Brown CB 1977 Studies on the mechanism of inhibition of adrenal steroidogenesis by organophosphate and carbamate compounds. Pesticide Biochemistry and Physiology $\mathbf{7}$ 169-182.

Clark BJ, Wells J, King SR \& Stocco DM 1994 The purification, cloning, and expression of a novel luteinizing hormone-induced mitochondrial protein in MA-10 mouse Leydig tumor cells. Characterization of the steroidogenic acute regulatory protein (StAR). Journal of Biological Chemistry 269 28314-28322.

Clark BJ, Soo SC, Caron KM, Ikeda Y, Parker KL \& Stocco DM 1995 Hormonal and developmental regulation of the steroidogenic acute regulatory protein. Molecular Endocrinology 9 1346-1355.

Clark BJ, Combs R, Hales KH, Hales DB \& Stocco DM 1997 Inhibition of transcription affects synthesis of steroidogenic acute regulatory protein and steroidogenesis in MA-10 mouse Leydig tumor cells. Endocrinology 138 4893-4901.

Dunnick JK, Gupta BN, Harris MW \& Lamb JCt 1984 Reproductive toxicity of dimethyl methyl phosphonate (DMMP) in the male Fischer 344 rat. Toxicology and Applied Pharmacology 72 379-387.

Garren LD, Ney RL \& Davis WW 1965 Studies on the role of protein synthesis in the regulation of corticosterone production by ACTH in vivo. PNAS 53 1443-1450.

Greenburg M \& Bender T 1998 Nuclear runoff transcription in mammalian cells. In Current Protocols in Molecular Biology, vol 1, unit 4·10. Ed K Janssen. New York: John Wiley \& Sons, Inc.

Haas PJ, Buck WB, Hixon JE, Shanks RD, Wagner WC, Weston PG \& Whitmore HL 1983 Effect of chlorpyrifos on Holstein steers and testosterone-treated Holstein bulls. American Journal of Veterinary Research 44 879-881.

Krause W 1977 Influence of DDT, DDVP and malathion on FSH, $\mathrm{LH}$ and testosterone serum levels and testosterone concentration in testis. Bulletin of Environmental Contamination and Toxicology 18 231-242.

Krause W \& Homola S 1974 Alterations of the seminiferous epithelium and the Leydig cells of the mouse testis after the application of dichlorvos (DDVP). Bulletin of Environmental Contamination and Toxicology 11 429-433.

Lin D, Sugawara T, Strauss JF 3rd, Clark BJ, Stocco DM, Saenger P, Rogol A \& Miller WL 1995 Role of steroidogenic acute regulatory protein in adrenal and gonadal steroidogenesis [see Comments]. Science 267 1828-1831.

Marinovich M, Guizzetti M \& Galli CL 1994 Mixtures of benomyl, pirimiphos-methyl, dimethoate, diazinon and azinphos-methyl affect protein synthesis in HL-60 cells differently. Toxicology 94 173-185. 
Nagy L \& Freeman DA 1990 Effect of cholesterol transport inhibitors on steroidogenesis and plasma membrane cholesterol transport in cultured MA-10 Leydig tumor cells. Endocrinology 126 2267-2276.

Nolan CJ \& Payne AH 1990 Genotype at the P450 scc locus determines differences in the amount of $\mathrm{P} 450 \mathrm{scc}$ protein and maximal testosterone production in mouse Leydig cells. Molecular Endocrinology 4 1459-1464.

Payne AH \& O'Shaughnessy PJ 1996 Structure, function and regulation of steroidogenic enzymes in the Leydig cell. In The Leydig Cell, pp 259-286. Eds AH Payne, MP Hardy \& LD Russel. Vienna, IL: Cache River Press.

Pope CN 1999 Organophosphorus pesticides: do they all have the same mechanism of toxicity? Journal of Toxicology and Environmental Health B Critical Reviews 2 161-181.

Reinhart AJ, Williams SC \& Stocco DM 1999 Transcriptional regulation of the StAR gene. Molecular and Cellular Endocrinology 151 161-169.

Resko JA, Norman RL, Niswender GD \& Spies HG 1974 The relationship between progestins and gonadotropins during the late luteal phase of the menstrual cycle in rhesus monkeys. Endocrinology 94 128-135.

Salem MH, Abo-Elezz Z, Abd-Allah GA, Hassan GA \& Shaker N 1988 Effect of organophosphorus (dimethoate) and pyrethroid (deltamethrin) pesticides on semen characteristics in rabbits. Journal of Environmental Science and Health B 23 279-290.

Simpson ER 1979 Cholesterol side-chain cleavage, cytochrome P450, and the control of steroidogenesis. Molecular and Cellular Endocrinology 13 213-227.

Stocco DM \& Kilgore MW 1988 Induction of mitochondrial proteins in MA-10 Leydig tumor cells with human choriogonadotropin. Biochemical Journal 249 95-103.

Stocco DM \& Clark BJ 1993 The requirement of phosphorylation on a threonine residue in the acute regulation of steroidogenesis in MA-10 mouse Leydig cells. Journal of Steroid Biochemistry and Molecular Biology 46 337-347.

Stocco DM \& Clark BJ 1996 Regulation of the acute production of steroids in steroidogenic cells. Endocrine Reviews 17 221-244.
Sutton HG, Fusco A \& Cornwall GA 1999 Cystatin-related epididymal spermatogenic protein colocalizes with luteinizing hormone-beta protein in mouse anterior pituitary gonadotropes. Endocrinology 140 2721-2732.

United States Department of Health and Human Services 1997 CERCLA Priority List of Hazardous Substances that will be the Subject of Toxicological Profiles and Support Document. United States Department of Health and Human Services, Washington, DC.

Walsh LP \& Stocco DM 1999 Econazole and miconazole inhibit steroidogenesis through a post-transcriptional reduction in steroidogenic acute regulatory (StAR) protein expression and induction of Leydig cell apoptosis. Biology of Reproduction $\mathbf{6 0}$ Abstract 202.

Walsh LP \& Stocco DM 2000a The effects of Lindane on steroidogenesis and steroidogenic acute regulatory protein expression. Biology of Reproduction (In Press).

Walsh LP \& Stocco DM $2000 b$ The role of the steroidogenic acute regulatory (StAR) protein in environmental endocrine disruptor inhibited steroidogenesis. Proceedings of the 52nd Yamada Conference, Molecular Steroidogenesis, pp 253-266. Tokyo, Japan: Universal Academy Press Inc.

Walsh LP, McCormick C, Martin C \& Stocco DM 2000 Roundup inhibits steroidogenesis by disrupting StAR expression. Environmental Health Perspectives (In Press).

Wang X, Liu Z, Eimerl S, Timberg R, Weiss AM, Orly J \& Stocco DM 1998 Effect of truncated forms of the steroidogenic acute regulatory protein on intramitochondrial cholesterol transfer. Endocrinology 139 3903-3912.

Xiong Y \& Hales DB 1997 Differential effects of tumor necrosis factor-alpha and interleukin-1 on 3 beta-hydroxysteroid dehydrogenase/delta $5 \rightarrow$ delta 4 isomerase expression in mouse Leydig cells. Endocrine 7 295-301.

Received 17 April 2000

Accepted 26 June 2000 